Katrina A. Morris, MD

Paddy Waters, PhD

Mark R. Woodhall, PhD

Wilhelm Kuker, MD, $\mathrm{PhD}$

Angela Vincent, FRCPath, FRS

Maria I. Leite, MD, DPhil

Arjune Sen, MD, PhD

Neurol Neuroimmunol

Neuroinflamm

2015;2:e88; doi: 10.1212/

NXI.0000000000000088

\section{A 41-YEAR-OLD WOMAN WITH ACUTE WEAKNESS AND ENCEPHALOPATHY ASSOCIATED WITH MOG ANTIBODIES \\ OPEN}

Antibodies to native glycosylated myelin oligodendrocyte glycoprotein (MOG), measured by cellbased assays, have been reported in adults with acute disseminated encephalomyelitis (ADEM) and in children with demyelinating diseases, including multiple sclerosis (MS) and ADEM. More recently, antibodies to both truncated ${ }^{1}$ and full-length ${ }^{2}$ MOG have been identified in a few adults with aquaporin-4 (AQP4) antibody-negative neuromyelitis optica spectrum disorder (NMOSD). We report a patient with a rapidly worsening longitudinally extensive transverse myelitis (LETM) whose serum antibodies were subsequently found to bind the full-length version of MOG. Aggressive and early immunomodulation correlated closely with reduction in MOG titer and clinical improvement.

Case report. A 41-year-old woman was transferred to our center with a 3-day history of rapidly ascending sensorimotor disturbance. She described initial sensory difficulties in the left leg that progressed over 48 hours to involve both lower limbs, followed by weakness and urinary retention. Over the first 12 hours of admission, her sensory symptoms progressed to involve the thorax. Within 72 hours of onset, she developed a flaccid paralysis below T1. She became drowsy and had a weak cough.

Examination revealed mild encephalopathy, subtle weakness in the right upper limb, and normal (not brisk) upper limb reflexes. She had a flaccid paralysis in the lower limbs with absent reflexes. There was loss of pinprick, temperature, and light touch below the T2 dermatome and hyperalgesia at T1. Proprioception was intact.

Complete blood count, erythrocyte sedimentation rate, biochemical profile, HIV serology, antinuclear antibodies, rheumatoid factor, and serum angiotensinconverting enzyme were all normal or negative. MRI on admission revealed extensive spinal cord hyperintensity extending from the high cervical cord to the midthoracic cord, and white matter changes in posterior fossa and cerebral hemispheres, which appeared to be inflammatory (figure, A). CSF analysis revealed a white cell count of $32 \times 10^{9} / \mathrm{L}$ (all lymphocytes), with paired oligoclonal bands in serum and CSF. A diagnosis of NMOSD was made.

Methylprednisolone $1 \mathrm{~g}$ was given daily for 5 days, followed by high-dose oral prednisolone ( $70 \mathrm{mg} /$ day). Five days of plasma exchange were performed, beginning on day 3 of symptoms. There was rapid improvement in encephalopathy. The sensory level descended to T4 and there was subtle lower limb improvement. After 3 weeks, plasma exchange was repeated, with further significant improvement in lower limb function and return of bladder control. Labile hypotension during plasma exchange was the only significant manifestation of autonomic dysfunction.

Cell-based assays for antibodies against AQP4 and the C-terminal-truncated human MOG were both negative (serum 1:20). However, subsequently the patient's serum was found to bind to full-length untagged human MOG (endpoint titer: 1:400). Titers of antibody to full-length untagged human MOG decreased in response to plasma exchange and weaning of oral steroids, paralleling the clinical progress (figure, C). Full-length untagged human MOG antibodies were negative by 6 months after presentation and remain negative more than 200 days after cessation of steroids (on day 180). No other immunosuppression was used. At 12 months after symptom onset, the patient has ongoing spasticity and mild sensory change but has returned to work as a nurse in primary care.

Discussion. In our patient, a diagnosis of NMOSD was favored over ADEM because the patient's presentation was of severe LETM with only mild encephalopathy. We acknowledge, however, that there is much overlap between the clinical-radiologic features of NMOSD and limited forms of ADEM, and the presence or absence of autoantibodies to MOG or AQP4 are probably the markers that distinguish them in terms of pathogenic mechanisms and outcome.

This case illustrates that MOG antibodies may be missed using cell-based assays employing the short form of $\mathrm{MOG}^{3}$ and that testing for antibodies against full-length MOG is necessary in patients with LETM who are negative for antibodies to AQP4. ${ }^{1,2,4}$ The extracellular domain of MOG is common to both forms of the antigen. It is unclear why deletion of 

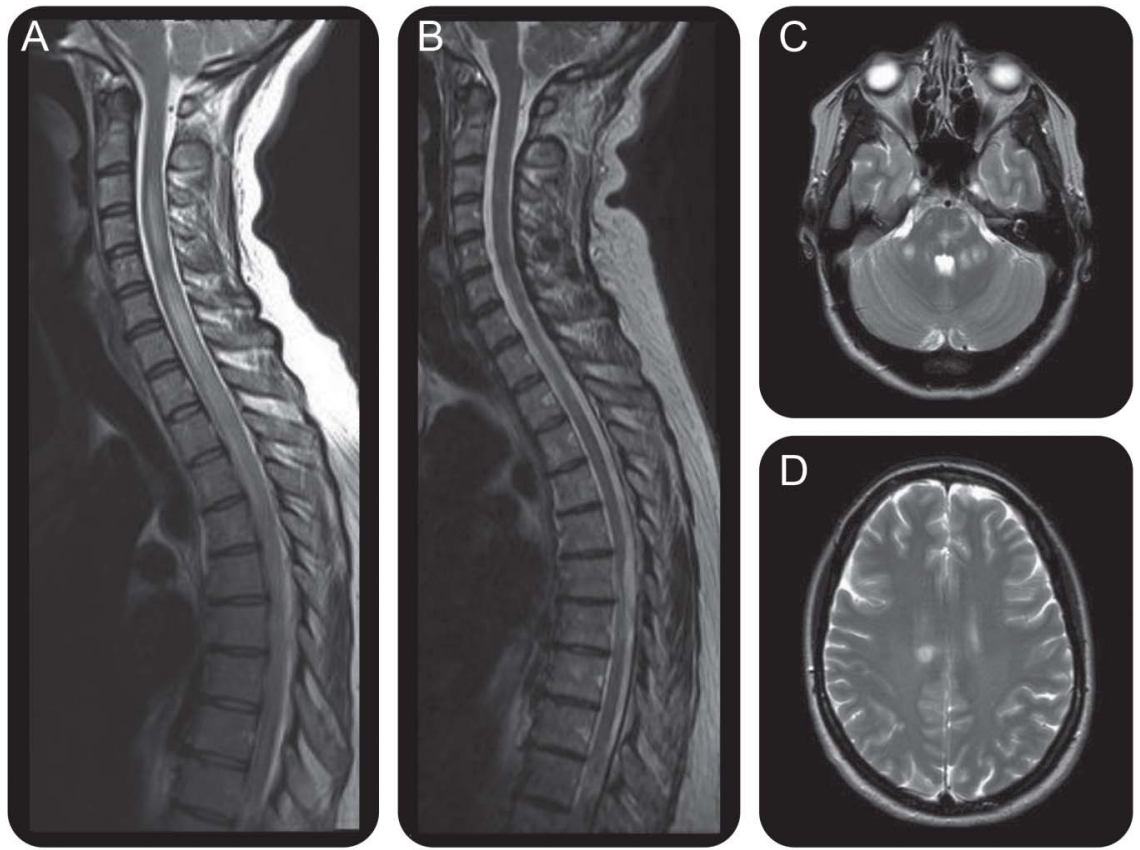

\section{$E$}
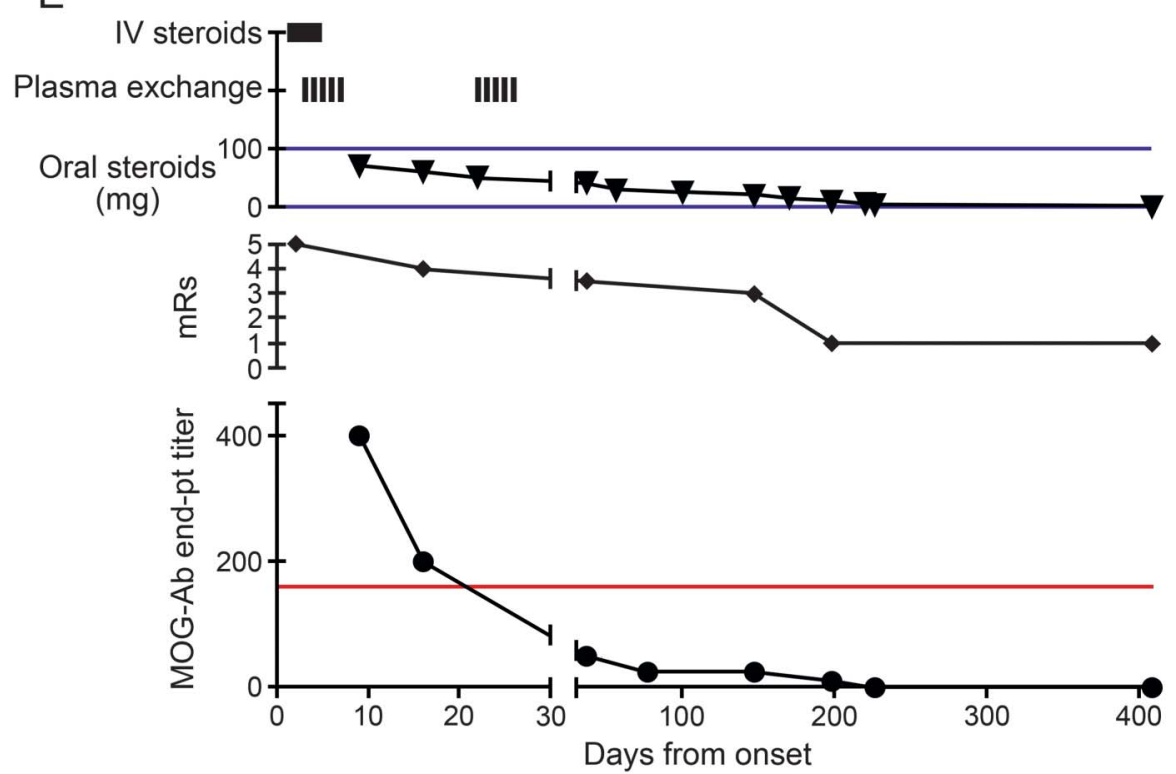

(A) The T2 contrast-enhanced sequence on day 3 shows an extensive central cord lesion extending from C2 to T7. The cord is swollen. Multiple areas of contrast enhancement were present throughout the cord (not shown). (B) Day 438: The cord edema has resolved and there is no longer contrast enhancement (not shown). Posterior fossa (C) and supratentorial (D) white matter changes were evident on a T2-weighted scan performed 3 days after symptom onset. These changes resolved on follow-up imaging (not shown). (E) The myelin oligodendrocyte glycoprotein antibody (MOG-Ab) titer fell rapidly following the commencement of immunotherapy (reference range $<1: 160$; red line). There was a steady improvement in modified Rankin Scale $(\mathrm{mRS})$ score over 200 days $(\mathrm{mRS}=1)$.

the cytosolic domain, which defines the short form, affects binding of antibodies to the extracellular domain, but it may be that this cytosolic domain affects surface expression of the protein or quaternary structure. This case demonstrates that using the fulllength form of MOG provides a more sensitive assay.

This case also exemplifies the need to consider aggressive immunotherapy in a patient in whom antibody-mediated disease is suspected, even if proof of a positive antibody is not immediately forthcoming. Furthermore, although MOG-associated disease has been suggested as having a good outcome, if acute treatment is delayed, complications of illness and long-term disability may occur.

From the Nuffield Department of Clinical Neurosciences, University of Oxford, UK. 
Author contributions: Dr. Morris: concept and design, acquisition of data, analysis and interpretation of results, care of patient. $D r$. Waters: acquisition of data, analysis and interpretation of results, critical revision of the manuscript. Dr. Woodhall: acquisition of data, critical revision of the manuscript for important intellectual content. Dr. Kuker: acquisition of data, analysis and interpretation of results. Prof. Vincent: critical revision of the manuscript for important intellectual content. Dr. Leite: concept and design, analysis and interpretation of results, care of patient. Dr. Sen: concept and design, analysis and interpretation of results, critical revision of the manuscript for important intellectual content, care of patient, overall supervision. Study funding: Oxford NIHR Biomedical Research Centre.

Disclosure: K.A. Morris reports no disclosures. P. Waters has received speaker honoraria from Biogen Idec Japan and Euroimmun AG; has been a review editor for Frontiers in Molecular Innate Immunity; and holds a patent for assays for the detection of antibodies to lgi, Caspr2, and tag-1. M.R. Woodhall reports no disclosures. W. Kuker is on the editorial board for Neuroradiology. A. Vincent has received travel funding and speaker honoraria from Baxter International Inc and Biogen Inc; is on the editorial board for Neurology; was an Associate Editor for Brain; holds patents with Oxford University for LGI1/CASPR2 antibodies, licensed to Euroimmun $A G$, and for $G A B A A R$ antibodies, in negotiation with Euroimmun $A G$; receives publishing royalties from Athena Diagnostics, Euroimmun $A G$, Blackwell Publishing, and Mac Keith Press; has consulted for Athena Diagnostics; and received research support from NIHR. M.I. Leite is supported by NHS National Specialised Commissioning Group for Neuromyelitis optica, UK and NIHR Oxford Biomedical Research Centre; has received speaking honoraria from Biogen Idec and travel and educational grants from Biogen Idec and UK; and is on the editorial board for $\mathrm{Neuromuscular}$ Disorders. A. Sen has received speaker honoraria and/or travel funding from UCB Pharma and Esai; is supported by the NIHR Oxford Biomedical Research Centre; and has received research support from Oxford Health Services Charities, John Radcliffe Hospital Oxford. Go to Neurology.org/nn for full disclosure forms. The Article Processing Charge was paid by the authors. This is an open access article distributed under the terms of the Creative Commons Attribution-Noncommercial No Derivative $3.0 \mathrm{Li}$ cense, which permits downloading and sharing the work provided it is properly cited. The work cannot be changed in any way or used commercially.

Received July 22, 2014. Accepted in final form January 16, 2015.

Correspondence to Dr.Sen: arjune.sen@ndcn.ox.ac.uk

1. Kitley J, Waters P, Woodhall M, et al. Neuromyelitis optica spectrum disorders with aquaporin-4 and myelinoligodendrocyte glycoprotein antibodies: a comparative study. JAMA Neurol 2014;71:276-283. doi: 10.1001/ jamaneurol.2013.5857.

2. Sato DK, Callegaro D, Lana-Peixoto MA, et al. Distinction between MOG antibody-positive and AQP4 antibodypositive NMO spectrum disorders. Neurology 2014;82: 474-481. doi: 10.1212/WNL.0000000000000101.

3. O'Connor KC, McLaughlin KA, De Jager PL, et al. Selfantigen tetramers discriminate between myelin autoantibodies to native or denatured protein. Nat Med 2007;13: 211-217.

4. Reindl M, Di Pauli F, Rostásy K, Berger T. The spectrum of MOG autoantibody-associated demyelinating diseases. Nat Rev Neurol 2013;9:455-461. doi: 10.1038/nrneurol. 2013.118 . 


\section{Neurology \\ Neuroimmunology \& Neuroinflammation}

\section{A 41-year-old woman with acute weakness and encephalopathy associated with MOG antibodies \\ Katrina A. Morris, Paddy Waters, Mark R. Woodhall, et al. \\ Neurol Neuroimmunol Neuroinflamm 2015;2; \\ DOI 10.1212/NXI.0000000000000088}

This information is current as of March 19, 2015

\section{Updated Information \& \\ Services}

References

Subspecialty Collections

Permissions \& Licensing

Reprints including high resolution figures, can be found at:

http://nn.neurology.org/content/2/3/e88.full.html

This article cites 4 articles, 0 of which you can access for free at: http://nn.neurology.org/content/2/3/e88.full.html\#\#ref-list-1

This article, along with others on similar topics, appears in the following collection(s):

All Demyelinating disease (CNS)

http://nn.neurology.org//cgi/collection/all_demyelinating_disease_cns

Information about reproducing this article in parts (figures,tables) or in its entirety can be found online at:

http://nn.neurology.org/misc/about.xhtml\#permissions

Information about ordering reprints can be found online: http://nn.neurology.org/misc/addir.xhtml\#reprintsus

Neurol Neuroimmunol Neuroinflamm is an official journal of the American Academy of Neurology.

Published since April 2014, it is an open-access, online-only, continuous publication journal. Copyright $\odot$ 2015 American Academy of Neurology. All rights reserved. Online ISSN: 2332-7812.

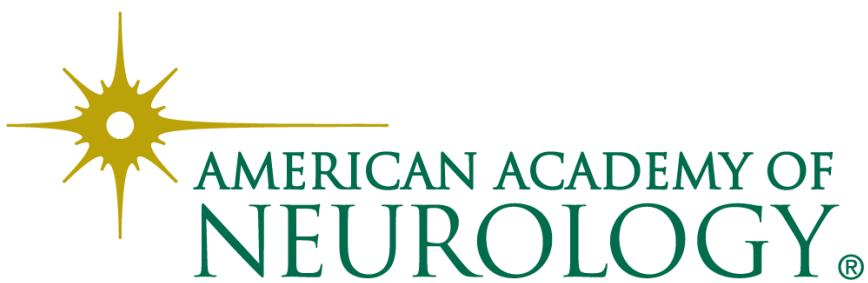

